\title{
Talaromikosis Marneffei
}

\author{
Sem S. Surja, ${ }^{1,2}$ Robiatul Adawiyah, ${ }^{3}$ Retno Wahyuningsih ${ }^{3,4 *}$
}

\begin{abstract}
Talaromycosis marneffei is a mycotic disease caused by Talaromyces marneffei which primarily infect immunocompromised patient. This disease is endemic in Southeast Asia, and Indonesia consider as endemic area due to a case of tourist who got the infection after visiting Indonesia. Diagnosis was made based on clinical suspicion with laboratory confirmation. Clinical manifestations are not specific, such as fever, anemia, weight loss, lymphadenopathy, hepatomegaly, splenomegaly, respiratory disorder, and cutaneous manifestation. Histopathology and culture are the most common examination performed for diagnosis. In histopathology examination, fungi appear as fission arthroconidia cells which shape round to oval, with cross wall formation inside or outside macrophage and histiocyte. Thermal dimorphism characteristic can be observed in fungal culture. Fungi grows as mold at $25^{\circ} \mathrm{C}-30^{\circ} \mathrm{C}$ and as yeast at $37^{\circ} \mathrm{C}$. Definitive identification of T. marneffei was done by molecular examination using primers derived from ITS region as primary marker and beta tubulin region as secondary marker. Talaromyces marneffei is sapronosis, that transmitted via inhalation of conidia from environment.
\end{abstract}

Keywords: Talaromycosis, Talaromyces marneffei, diagnosis, epidemiology

Talaromikosis (dahulu penisiliosis) merupakan penyakit akibat infeksi jamur genus Talaromyces. Talaromyces marneffei merupakan penyebab tersering talaromikosis, ${ }^{1}$ walaupun pernah dilaporkan isolasi spesies lain bahan klinik..$^{2-7}$ Talaromikosis marneffei menjadi perhatian sejak adanya pandemi HIV/AIDS di Asia Tenggara. Kasusnya meningkat tajam di negara-negara seperti Thailand, Vietnam, Tiongkok, Malaysia, dan negara di benua Asia lainnya. ${ }^{1}$ Indonesia dikenal sebagai negara endemis karena ada laporan kasus turis asing pasien HIV yang didiagnosis sebagai talaromikosis marneffei setelah berkunjung ke Indonesia. ${ }^{8}$

Talaromikosis marneffei memiliki prognosis baik jika terdiagnosis sejak dini namun keterlambatan diagnosis dapat berakibat fatal. ${ }^{1,9}$ Kendala diagnosis

\footnotetext{
* Email korespondensi : retnet2002@gmail.con

1 Program Studi Magister Ilmu Biomedik Fakultas Kedokteran Universitas Indonesia

2 Departemen Parasitologi Fakultas Kedokteran Universitas Katolik Indonesia Atma Jaya

3 Departemen Parasitologi Fakultas Kedokteran Universitas Indonesia

4 Departemen Parasitologi Fakultas Kedokteran Universitas Kristen Indonesia
}

penyakit ini terletak pada tanda dan gejala yang tidak khas. Demam, anemia, penurunan berat badan, limfadenopati, hepatomegali, splenomegali, gangguan pernapasan, dan kelainan kulit merupakan bentuk kelainan yang sering ditemukan. . $^{1,9,10,11}$ Pemeriksaan laboratorium seperti pemeriksaan mikroskopis untuk menemukan elemen jamur, kultur bahan klinik, pemeriksaan serologi, atau bahkan pemeriksaan berbasis molekular sering diperlukan untuk menegakkan diagnosis. ${ }^{1}$ Kesulitannya adalah belum banyak fasilitas kesehatan di Indonesia yang mampu melakukan pemeriksaan mikologi dengan baik.

Tingginya angka kejadian talaromikosis marneffei di Asia Tenggara menimbulkan kecurigaan adanya fenomena gunung es penyakit tersebut di Indonesia. Hal itu mengindikasikan perlunya pemahaman mengenai talaromikosis bagi klinisi dan ahli parasitologi kedokteran untuk tatalaksana pasien maupun penanganan/pencegahan di komunitas karena penyakit tersebut merupakan mikosis endemik. Makalah ini akan membahas secara garis besar talaromikosis marneffei pada manusia, perkembangan terkini, serta hal-hal yang masih menjadi masalah sampai saat ini. 


\section{TALAROMIKOSIS MARNEFFEI}

\section{Sejarah T. marneffei}

Talaromyces marneffei pertama kali diisolasi dari hati tikus bambu (Rhizomys sinensis) pada tahun 1956 yang kemudian mati karena mikosis retikuloendotelial. Kasus pertama talaromikosis marneffei pada manusia terjadi pada tahun 1959. Segretain mengalami infeksi secara tidak sengaja karena tertusuk jarum yang mengandung jamur. Infeksi alamiah pertama pada manusia dilaporkan pada tahun 1973. Pasien adalah seorang Amerika yang tinggal di Asia Tenggara. Pasien ini diketahui menderita penyakit Hodgkin sebelumnya dan $T$. marneffei ditemukan secara tidak sengaja pada limpa pasien saat menjalani splenektomi sebagai prosedur standar penanganan penyakit Hodgkin. ${ }^{12}$

Kejadian talaromikosis marneffei mulai meningkat seiring dengan pandemi HIV/AIDS di Asia Tenggara pada tahun 1988 sampai tahun 1990an. ${ }^{1,13-15}$ Thailand merupakan negara dengan pasien talaromikosis terbanyak, namun penyakit tersebut juga ditemukan di beberapa negara Asia seperti Kamboja, Tiongkok, Hong Kong, India, Malaysia, Taiwan, dan Vietnam. Kejadian talaromikosis yang ditemukan di luar Asia umumnya berhubungan dengan infeksi HIV dan riwayat bepergian ke negara endemis. ${ }^{1,16}$ Indonesia dikenal sebagai negara endemis karena dilaporkan terdapat kasus turis asing pasien HIV yang didiagnosis sebagai talaromikosis marneffei setelah berkunjung ke Indonesia. $^{8}$

Seiring berkembangnya pengobatan dan pencegahan transmisi HIV, kejadian talaromikosis menurun. Pola seperti itu tampak di Thailand, Vietnam, dan Tiongkok. ${ }^{1,13,15}$ Saat ini talaromikosis marneffei juga ditemukan pada pasien defisiensi imun lain maupun pasien tanpa komorbid yaitu penerima imunosupresan dosis tinggi misalnya pasien transplantasi organ, pasien penyakit autoimun, kanker, penyakit bawaan, dan lain-lain. ${ }^{14}$ Sejarah talaromikosis marneffei secara ringkas dapat dilihat pada Gambar 1.

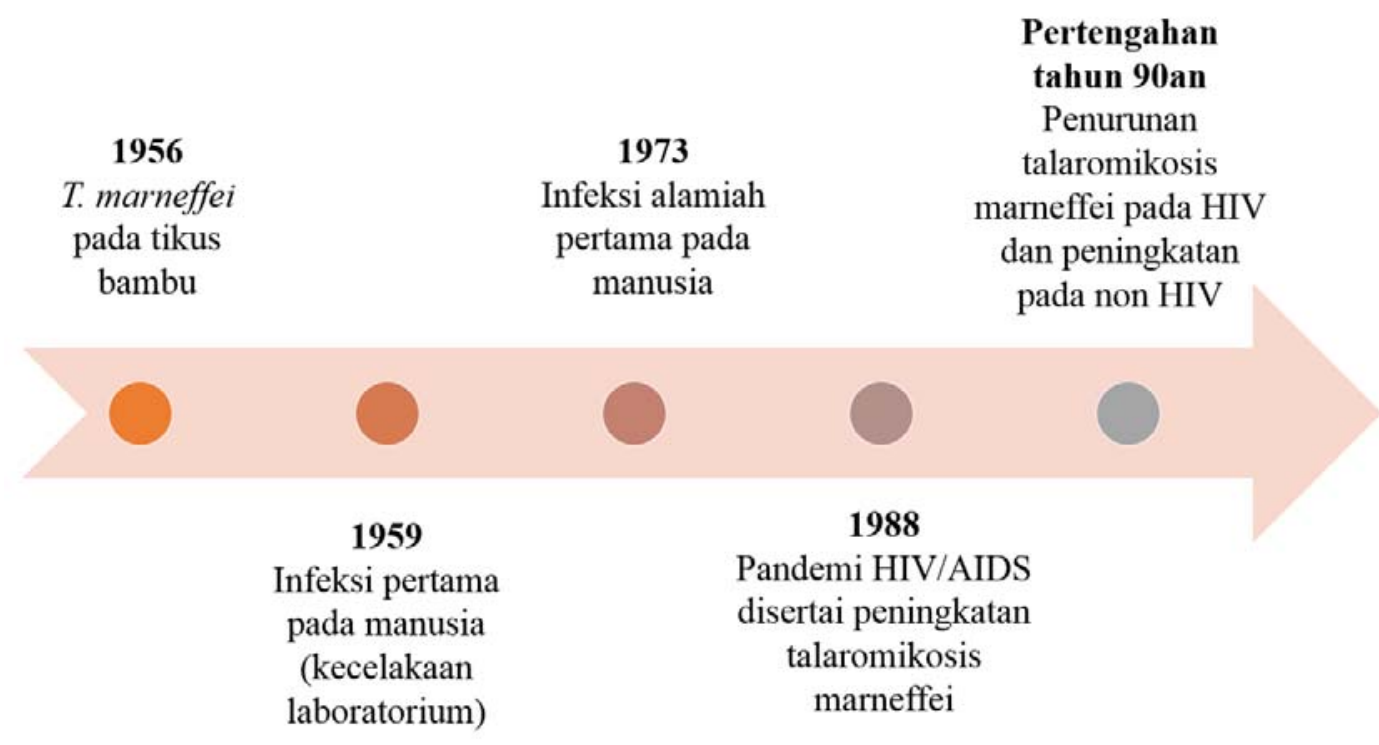

Gambar 1. Sejarah T. marneffei dan talaromikosis marneffei

\section{Biologi T. marneffei}

Talaromyces marneffei awalnya masuk ke dalam genus Penicillium karena struktur mikroskopisnya yang mirip dengan genus Penicillium, berupa hifa bersekat yang kemudian membentuk konidiofora dan konidia. ${ }^{1}$ Perbedaannya adalah genus Talaromyces membentuk dua lapis konidiofora yang simetris, sehingga dahulu diklasifikasikan ke dalam subgenus Biverticillatae. ${ }^{17}$ Talaromyces marneffei merupakan satu-satunya genus Talaromyces yang memiliki sifat dimorfisme termal yaitu mempunyai dua morfologi yang berbeda 
pada suhu yang berbeda. Pada $25^{\circ} \mathrm{C}-30^{\circ} \mathrm{C}$, jamur berbentuk kapang, sedangkan pada suhu $37^{\circ} \mathrm{C}$ membentuk ragi. ${ }^{1,18,19}$ Sifat tersebut menyebabkan T. marneffei mampu menginfeksi manusia.

Pertumbuhan T. marneffei berawal dari pertumbuhan konidia yang dihasilkan oleh kapang di alam, yang akan berubah menjadi sel ragi di dalam tubuh manusia. Perubahan itu terjadi melalui berbagai tahapan yaitu germinasi konidia, pertumbuhan hifa dan polaritas, morfogenesis perkembangan aseksual, dan morfogenesis perkembangan seksual (Gambar 2). Di alam, pertumbuhan T. marneffei diawali oleh germinasi konidia. Semula germinasi berlangsung isotropik (pembesaran konidia ke segala arah), diikuti pembentukkan aksis terpolarisasi untuk membentuk germ tube/kecambah. Setelah itu pertumbuhan hifa berlangsung mengikuti aksis polarisasi. Sel hifa apikal multinukleat, sedangkan sel hifa subapikal uninukleat. Hifa mengalami sitokinesis tanpa pembelahan sel untuk membentuk septa dan bercabang pada titik tertentu. Pertumbuhan hifa terpolarisasi tidak lepas dari berkumpulnya aktin pada bagian apikal hifa. Pada suhu $25^{\circ} \mathrm{C}$, pajanan udara dan cahaya pada sel hifa yang telah berkembang memicu diferensiasi aseksual untuk membentuk spora aseksual (konidia). Sel hifa yang terpajan kondisi ini dapat membentuk cabang berturut-turut menjadi konidiofora, metulae, phialid dan membentuk konidia. ${ }^{20}$

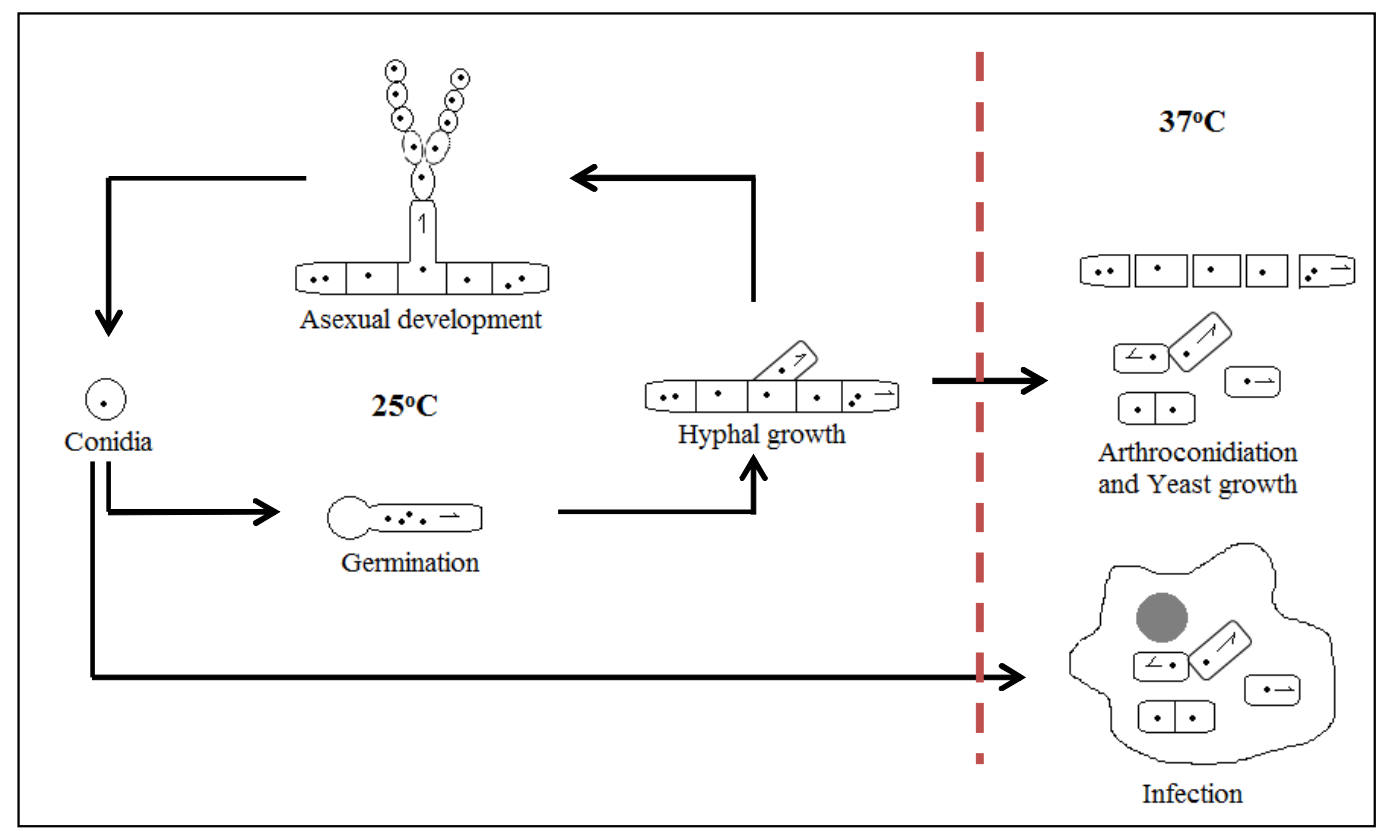

Gambar 2. Morphogenesis of T. marneffei ${ }^{20}$

Transisi morfogenesis T. marneffei terjadi pada sel hifa pada suhu $37^{\circ} \mathrm{C}$ atau dalam sel fagosit. Secara in vitro terjadi artrokonidiasi sel hifa yaitu fragmentasi hifa pada septa membentuk sel ragi bersel satu (artrokonidia). Sel-sel tersebut selanjutnya berkembang dengan membelah diri. Secara makroskopis tampak koloni sel ragi tanpa perubahan warna media. Pada in vivo atau dalam tubuh manusia, artrokonidiasi tidak terjadi. Konidia yang terhirup oleh manusia akan masuk ke dalam paru dan difagosit oleh sel fagosit. Dalam sel fagosit, konidia langsung mengalami germinasi dan berubah menjadi sel ragi. ${ }^{20}$

\section{Patogenesis talaromikosis marneffei}

Talaromyces marneffei membentuk konidiofora dan konidia (spora) di alam. ${ }^{1}$ Konidia mudah menyebar dan masuk ke dalam tubuh manusia melalui inhalasi. ${ }^{18}$ Beberapa penelitian menunjukkan bahwa jamur ini paling banyak diisolasi dari paru, ${ }^{21-}$ ${ }^{23}$ diikuti hati dan limpa. ${ }^{22,23}$ Hal tersebut mendukung teori bahwa patogenesis T. marneffei yang diawali inhalasi konidia dari alam kemudian menyebar ke organ lain secara hematogen. ${ }^{1}$

Konidia Talaromyces memiliki ukuran kecil sehingga mudah mencapai alveolus. Konidia yang 
masuk ke paru mengalami beberapa proses sebelum menyebabkan infeksi pada manusia. Konidia akan berinteraksi dengan glikoprotein matriks ekstraseluler, fibronectin, dan laminin melalui sialic acid-specific lectin pada sel epitel bronkoalveolar pejamu. Sel fagosit sebagai lini pertama pertahanan tubuh terhadap T. Marneffei akan melakukan fagositosis konidia yang masuk. Aktivasi makrofag oleh sel Th1 dengan perantaraan sitokin seperti IFN${ }^{3}$, IL-12 danTNF- \pm merupakan respons lanjutan untuk mengeliminasi T. marneffei. ${ }^{1,14}$ Pada individu imunokompeten, T. marneffei dapat tereliminasi dalam waktu 2-3 minggu. ${ }^{1}$

Bila respons imun tersebut gagal maka akan terjadi manifestasi klinik talaromikosis marneffei. Talaromyces marneffei memiliki kemampuan bertahan dalam lingkungan tidak menguntungkan di dalam sel fagosit bahkan mampu melakukan proliferasi dengan cara membelah diri di dalam sel fagosit. ${ }^{18}$ Derajat keparahan infeksi bervariasi tergantung pada derajat imunokompromi. Pasien dengan HIV umumnya memiliki infeksi diseminata yang meliputi berbagai organ. Pasien non-HIV dapat mengalami manifestasi klinik berupa infeksi fokal maupun diseminata tergantung dari penyebab imunokompromi dan kecepatan diagnosis penyakit. ${ }^{14}$

\section{Diagnosis talaromikosis marneffei}

\section{Manifestasi klinik}

Talaromikosis marneffei umumnya memiliki manifestasi klinik yang tidak spesifik. Berbagai penelitian di Asia menunjukkan persentase timbulnya manifestasi klinik berbeda-beda di setiap tempat (Tabel 1). ${ }^{9,11,14-16}$ Demam, anemia dan penurunan berat badan merupakan manifestasi klinik yang paling sering ditemukan. Pasien dapat memiliki lesi kulit dengan gambaran bermacam-macam seperti lesi menyerupai abses subkutan, ulkus dan papul menyerupai moluscum contangiosum. Manifestasi klinik lain yang dapat ditemui adalah limfadenopati, hepatosplenomegali, batuk, diare, perikarditis, lesi osteolitik, artritis dan lain-lain. Demam dan splenomegali lebih banyak terjadi pada pasien dengan HIV sedangkan infeksi pada tulang dan sendi lebih sering terjadi pada pasien non HIV. ${ }^{14}$ Manifestasi klinik pada talaromikosis tidak khas, oleh karena itu dapat terjadi kesalahan diagnosis ataupun tidak terdiagnosis. ${ }^{24}$ Kesulitan memastikan diagnosis hanya berdasarkan gejala klinik inilah yang mengharuskan kecurigaan talaromikosis marneffei dipastikan dengan pemeriksaan laboratorium.

Tabel 1. Manifestasi klinik pada berbagai negara ${ }^{9,11,14-16}$

\begin{tabular}{|c|c|c|c|c|c|c|}
\hline \multirow{2}{*}{$\begin{array}{c}\text { Manifestasi } \\
\text { klinik }\end{array}$} & \multirow{2}{*}{$\begin{array}{c}\text { Gabungan } \\
\text { berbagai } \\
\text { negara }^{11} \\
\end{array}$} & \multirow[b]{2}{*}{ Thailand $^{16}$} & \multirow[b]{2}{*}{ Hongkong $^{9}$} & \multirow[b]{2}{*}{ Tiongkok $^{15}$} & \multicolumn{2}{|c|}{ Tiongkok $^{14}$} \\
\hline & & & & & HIV & non HIV \\
\hline Demam & 98 & 86 & 96 & 94,6 & 81,7 & 64,7 \\
\hline Anemia & 74,8 & N/A & 79 & 85,2 & 6,9 & 0 \\
\hline Penurunan BB & 71,6 & 96 & N/A & 93 & $\mathrm{~N} / \mathrm{A}$ & N/A \\
\hline Lesi kulit & 69,7 & 85,1 & 18 & 73,5 & 40,5 & 41,2 \\
\hline Limfadenopati & 52,3 & 83,8 & 62 & 67,2 & 31,9 & 38,2 \\
\hline Batuk & 49,7 & 31,1 & 40 & 71,1 & 27,6 & 23,5 \\
\hline Hepatomegali & 43,9 & 64,9 & 28 & & 36,2 & 17,6 \\
\hline Splenomegali & 13,5 & 23 & 15 & 67,2 & 21,6 & 5,9 \\
\hline Diare & 23,2 & 14,9 & 15 & N/A & 12,9 & 5,9 \\
\hline Pericarditis & 4,5 & N/A & N/A & N/A & N/A & N/A \\
\hline Lesi osteolitik & 3,9 & N/A & $\mathrm{N} / \mathrm{A}$ & N/A & & \\
\hline Atritis & 3,9 & N/A & N/A & N/A & 0 & 14,7 \\
\hline
\end{tabular}

N/A - not available. 
Pemeriksaan Laboratorium (morfologis dan serologi)

Pemeriksaan laboratorium T. marneffei meliputi pemeriksaan langsung termasuk pemeriksaan histopatologi, kultur dan serologi. Pemeriksaan histopatologi dan kultur merupakan pemeriksaan yang paling sering dilakukan untuk deteksi jamur. Pemeriksaan histopatologi dapat mendeteksi jamur dari berbagai bahan klinik. Jamur tampak sebagai fission arthroconidia, sel bulat sampai oval yang dapat membelah dengan penampakan cross wall formation di dalam makrofag atau histiosit. Gambaran jamur ekstraselular juga dapat muncul pada beberapa pemeriksaan. ${ }^{18}$ Kultur dilakukan sebagai konfirmasi pemeriksaan histopatologi. Sifat dimorfisme merupakan kunci identifikasi T. marneffei. Pada suhu $25^{\circ} \mathrm{C}-30^{\circ} \mathrm{C}$ jamur tampak sebagai koloni kapang seperti beledru atau seperti bubuk berwarna abu-abu kebiruan sampai hijau pada hari-hari pertama kemudian berubah warna menjadi kuning

Tabel 2. Pemeriksaan serologi T. marneffei dan membentuk pigmen yang terserap pada medium dan mengakibatkan perubahan warna media menjadi merah. Pada suhu $37^{\circ} \mathrm{C}$, jamur tampak sebagai koloni ragi. ${ }^{1,18,19}$

Pemeriksaan serologi dilakukan untuk mendeteksi antigen jamur atau antibodi terhadap jamur yang beredar dalam darah (Tabel 2). Sampai saat ini belum ada pemeriksaan serologi yang cukup baik untuk T. marneffei. Pemeriksaan antibodi terhadap sel ragi dan fission arthroconidia memiliki sensitivitas yang rendah. ${ }^{25,26}$ Pemeriksaan antibodi terhadap Mp1p yang berasal dari dinding sel $T$. marneffei memberikan sensitivitas $80 \%$ dan spesifisitas $100 \%$ pada pasien HIV. ${ }^{27}$ Pemeriksaan antibodi memiliki kesulitan karena sebagian besar pasien talaromikosis marneffei berada pada kondisi imunokompromi dan kebanyakan tidak mampu membentuk antibodi. Untuk mengatasi masalah tersebut dikembangkan metode deteksi antigen. Antigen yang dideteksi antara lain antigen fission arthroconidia dan Mp1p. Kendalanya sensitivitas pemeriksaan antigen tersebut masih di bawah $80 \%$.

\begin{tabular}{lll}
\hline Peneliti & Metode & Deskripsi \\
\hline Viviani et $a l^{25}$ & $\begin{array}{l}\text { Deteksi antibodi terhadap } \\
\text { eksoantigen (1 pasien) }\end{array}$ & $\begin{array}{l}\text { Positif pada 2 bulan pertama post terapi dan negatif pada } \\
\text { bulan selanjutnya }\end{array}$ \\
\hline $\begin{array}{l}\text { Kaufman } \text { et } \\
l^{26}\end{array}$ & $\begin{array}{l}\text { Deteksi antibodi terhadap } \\
\text { fission arthroconidia dan sel } \\
\text { ragi }\end{array}$ & dua dari 17 pasien terdeteksi positif \\
\hline Cao et $a l^{27}$ & $\begin{array}{l}\text { Deteksi antibodi terhadap } \\
\text { Mp1p }\end{array}$ & sensitivitas $80 \%$ dan spesifisitas $100 \%$ \\
\hline $\begin{array}{l}\text { Kaufman } \text { et } \\
a l^{26}\end{array}$ & $\begin{array}{l}\text { Deteksi antigen fission } \\
\text { arthroconidia }\end{array}$ & Deteksi $76,5 \%$ pasien \\
\hline Cao et $a l^{28}$ & Deteksi antigen Mp1p & Deteksi $65 \%$ pasien \\
\hline
\end{tabular}

Banyak pilihan pemeriksaan serologi spesifik T. marneffei namun tidak satupun pemeriksaan tersebut yang tersedia secara komersial. Sebuah pilihan yaitu menggunakan uji galaktomanan (GM) dalam serum pasien. Galaktomanan merupakan heteropolisakarida yang terdiri atas inti mannan nonimunogenik dan ikatan samping galaktofuransil imunoreaktif yang terdapat pada dinding sel sebagian besar spesies Aspergillus dan Penicillium. Uji GM telah menjadi standar untuk infeksi Aspergillus sehingga kit pemeriksaan ini sudah tersedia. Huang et al. menguji adanya GM dalam serum pasien talaromikosis dan didapatkan sebanyak $73,3 \%$ pasien memberikan hasil positif melalui pemeriksaan ini (GM optical density > 0,5). Uji GM dapat dipakai sebagai alternatif uji tapis talaromikosis di daerah endemis. $^{29}$ 


\section{Pemeriksaan Molekular}

Polymerase Chain Reaction (PCR) merupakan metode sensitif untuk deteksi jamur. ${ }^{1}$ Primer yang dirancang untuk regio ITS1-5,8S rDNAITS2 yakni primer ITS1-ITS4 merupakan primer universal yang dipakai untuk deteksi/identifikasi jamur. Primer yang dirancang dari wilayah tersebut merupakan primer utama deteksi T. marneffei. Selain region ITS1-5,8S rDNA-ITS2 dapat digunakan regio lain seperti beta tubulin (BenA), RNA polymerase II second largest subunit (RPB2), dan Calmodulin (CaM). Dua wilayah yakni ITS1-5,8S rDNA-ITS2 dan BenA direkomendasikan sebagai penanda primer dan sekunder pada T. marneffei. ${ }^{19}$ Regio lain yang beberapa kali dipakai dalam identifikasi molekular T. marneffei adalah regio $18 \mathrm{~S}$ rDNA, D2 (bagian dari 28S rDNA), dan MP1. ${ }^{10,30-}$ ${ }^{32}$ Identifikasi molekular T. marneffei telah terbukti berhasil dilakukan pada kultur jamur berusia minimal tujuh hari. ${ }^{19}$

Isolasi DNA dari koloni jamur akan menjamin keberhasilan PCR karena jumlah jamur/DNA lebih banyak setelah koloni jamur tumbuh pada medium kultur. Tantangan selanjutnya adalah melakukan deteksi/identifikasi jamur secara molekular dari bahan klinik. Sensitivitas dan spesifisitas pemeriksaan molekular pada bahan klinik belum cukup baik. Sensitivitas identifikasi molekular menggunakan serum, plasma atau whole blood pasien hanya berkisar sekitar $60-70 \%$ sedangkan spesifisitasnya mencapai $100 \% .{ }^{32-34}$ Sehingga dapat disimpulkan hasil negatif pemeriksaan molekular pada bahan klinik dapat digunakan untuk menyingkirkan diagnosis talaromikosis.

\section{Epidemiologi talaromikosis merneffei}

Penetapan sumber infeksi T. marneffei penting untuk pencegahan infeksi di masa depan. Sumber penularan T. marneffei saat ini masih menjadi perdebatan apakah bersifat zoonotik atau sapronotik. ${ }^{1}$

Talaromyces marneffei awalnya dicurigai sebagai penyakit transmisi zoonotik yang ditularkan melalui hewan. Jamur ini berulang kali diisolasi dari tikus bambu seperti Rhizomys sinensis, Rhizomys pruinosus, Rhizomys sumatrensis, dan Cannomys badius. ${ }^{1,21-23,35}$ Penelitian epidemiologi molekular menemukan persamaan tipe mikrosatelit antara pasien yang menderita talaromikosis marneffei dengan isolat yang berasal dari tikus bambu pada daerah yang sama. ${ }^{22,35}$ Menjadi pertanyaan apakah tikus hanya merupakan reservoar di alam, sementara penularan terjadi karena inhalasi jamur yang bersumber dari lingkungan.

Kecurigaan akan transmisi sapronotik $T$. marneffei tampak dalam beberapa penelitian epidemiologi. Chariyalertsak et al. ${ }^{36}$ menemukan risiko infeksi T. marneffei lebih tinggi pada pasien dengan pekerjaan yang sering terpajan tanah, sedangkan pajanan dan konsumsi tikus bambu tidak menjadi risiko infeksi. Data epidemiologi lain di Thailand dan Vietnam menunjukkan bahwa infeksi T. marneffei berhubungan dengan musim, pada musim hujan dtemukan lebih banyak kasus talaromikosis. ${ }^{13,37}$

Indikasi bahwa T. marneffei memiliki transmisi sapronotik harus didukung dengan penemuan sumber lingkungan. Tidak banyak penelitian epidemiologi yang berhasil mengisolasi T. marneffei dari tanah (0-8,2\%) yang dianggap sebagai sumber Talaromyces. Sulitnya isolasi dari lingkungan dicurigai akibat kemampuan kompetisi yang kurang atau kebutuhan akan lingkungan khusus untuk pertumbuhan T. marneffei di alam. ${ }^{38}$ Sebagian besar sumber tanah positif merupakan lubang masuk tikus bambu..$^{21,23,35,38}$ Saat ini diyakini bahwa transmisi $T$. marneffei adalah sapronotik, yaitu melalui inhalasi konidia di lingkungan. Transmisi zoonotik tidak dapat dibuktikan karena tidak jelas bagaimana terjadi penularan dari tikus bambu ke manusia. Dicurigai tikus bambu memang merupakan reservoar alamiah T. marneffei, namun sulit untuk membuktikan penularan dari tikus ke manusia.

\section{Talaromikosis oleh Talaromyces selain $T$. marneffei}

Talaromyces marneffei merupakan spesies utama penyebab talaromikosis. Namun terdapat beberapa spesies Talaromyces lain yang dapat diisolasi dari bahan klinik. Beberapa diantaranya bahkan pernah dilaporkan menyebabkan kematian pada manusia (Tabel 3). Data talaromikosis akibat infeksi non T. marneffei tersebut masih sangat jarang. Sebagian laporan kasus menunjukkan infeksi 
akibat jamur ini juga terjadi pada pasien imunokompromi. ${ }^{2-4,7}$ Sebagian lainnya tidak menampilkan riwayat penyakit dengan jelas. ${ }^{5,6}$ Gambaran klinik dan epidemiologi talaromikosis akibat jamur ini belum diketahui secara pasti. Sebagian besar sumber bahan klinik adalah dari paru (sputum, BAL, hasil aspirasi jarum halus), ${ }^{2,3,5-7}$ mengindikasikan penularan berasal dari inhalasi konidia, seperti T. marneffei. Uniknya semua kasus tersebut tidak ditemukan di Asia, ${ }^{2-7}$ padahal Asia merupakan daerah endemis talaromikosis marneffei. ${ }^{1}$

Tabel 3. Talaromyces non T. marneffei yang ditemukan dalam bahan klinik

\begin{tabular}{|c|c|c|c|c|}
\hline $\begin{array}{c}\text { Penulis (negara, } \\
\text { tahun) }\end{array}$ & Spesies penyebab & Faktor risiko & $\begin{array}{l}\text { Manifestasi } \\
\text { klinik }\end{array}$ & Bahan klinik \\
\hline $\begin{array}{l}\text { Horre E } \\
(\text { Germany, 2001) }\end{array}$ & T. piceum & cholangiocarcinoma & Infeksi paru & Kultur darah \\
\hline $\begin{array}{l}\text { Santos PE } \\
\text { (Argentina, } \\
2006)^{7}\end{array}$ & T. piceum & $\begin{array}{l}\mathrm{X} \text {-linked chronic } \\
\text { granulomatous } \\
\text { disease (X-CGD) }\end{array}$ & $\begin{array}{l}\text { Nodul paru dan } \\
\text { osteomielitis } \\
\text { tulang rusuk }\end{array}$ & $\begin{array}{l}\text { Hasil aspirasi } \\
\text { jarum halus dari } \\
\text { nodul paru dan } \\
\text { tulang }\end{array}$ \\
\hline $\begin{array}{l}\text { Guevara-Suarez } \\
\text { M (USA, 2016) }\end{array}$ & $\begin{array}{l}\text { T. amestolkiae, } T \text {. } \\
\text { purpureogenus, } T \text {. } \\
\text { pinophilus, } T \text {. } \\
\text { aurantiacus, } T \text {. } \\
\text { ruber, } T \text {. cnidii, } T \text {. } \\
\text { funiculosus, } T . \\
\text { columbinus, } T . \\
\text { atroroseus, } T . \\
\text { diversus }\end{array}$ & tidak ada data & tidak ada data & $\begin{array}{l}\text { Sebagian besar } \\
\text { BAL }\end{array}$ \\
\hline $\begin{array}{l}\text { Atalay A } \\
(\text { Turkey, 2016) }\end{array}$ & T. purpureogenus & Multiple myeloma & Infeksi paru & Sputum \\
\hline $\begin{array}{l}\text { Villanueva- } \\
\text { Lozano H } \\
(\text { Mexico, 2017) }\end{array}$ & T.amestolkiae & $\begin{array}{l}\text { Leukemia } \\
\text { limfoblastik akut, } \\
\text { kemoterapi, } \\
\text { transplantasi sumsum } \\
\text { tulang, konsumsi } \\
\text { imunosurpresan }\end{array}$ & Infeksi paru & BAL \\
\hline $\begin{array}{l}\text { Guevara-Suarez } \\
\text { M (USA, 2017) }\end{array}$ & $\begin{array}{l}\text { T. alveolaris, } T \text {. } \\
\text { georgiensis, } T \text {. } \\
\text { kabodanensis, } T \text {. } \\
\text { minnesotensis, } T \text {. } \\
\text { rapidus, } T \text {. } \\
\text { subaurantiacus }\end{array}$ & tidak ada data & tidak ada data & $\begin{array}{l}\text { BAL, telinga, } \\
\text { joint-fluid } \\
\text { (hewan) }\end{array}$ \\
\hline
\end{tabular}

BAL: bronchoalveolar lavage

\section{Talaromikosis di Indonesia}

Indonesia dikenal sebagai negara endemis, satu laporan kasus pasien HIV asal Belanda yang didiagnosis sebagai talaromikosis marneffei setelah berkunjung ke Sumatera, Indonesia. ${ }^{8}$ Selain itu dua kasus talaromikosis marneffei lain pernah dilaporkan mungkin berasal dari Indonesia, satu kasus pasien HIV yang memiliki riwayat berkunjung ke beberapa negara Asia Tenggara termasuk Indonesia dan satu kasus warga Tiongkok penerima transplan ginjal yang tinggal di Indonesia. ${ }^{10,39}$ Semua kasus tersebut tidak didiagnosis di Indonesia (Belanda dan Tiongkok). Belum ada kasus talaromikosis marneffei yang di 
diagnosis di Indonesia.

Satu kasus talaromikosis non T. marneffei pernah dilaporkan di Jakarta, Indonesia (Wahyuningsih et al, submitted). Pasien terinfeksi HIV dan memiliki lesi kulit pada wajah dan tubuh bagian atas. Jamur diisolasi dari spesimen kulit yang diambil dengan touch biopsy dan diidentifikasi secara morfologis sebagai Talaromyces sp. dan secara molekular sebagai T. atroroseus. Penemuan ini semakin meningkatkan kecurigaan fenomena gunung es kasus talaromikosis di Indonesia.

\section{SIMPULAN}

Talaromikosis marneffei merupakan penyakit jamur sistemik yang disebabkan T. marneffei yang sering kali menyerang individu imunokompromi. Manifestasi klinik penyakit ini tidak khas sehingga membutuhkan pemeriksaan penunjang untuk menegakkan diagnosis. Pemeriksaan histopatologi dan kultur jamur menjadi pemeriksaan yang paling sering dan mudah dilakukan. Diagnosis pasti penyakit ditegakkan melalui penemuan/isolasi jamur dari bahan klinik. Identifikasi jamur dapat dilakukan berdasarkan morfologi, namun hasil pasti dilakukan dengan pemeriksaan berbasis molekular. Kasus talaromikosis marneffei masih jarang di Indonesia, padahal penyakit ini endemis di Asia Tenggara dan pernah dilaporkan kasus-kasus asal Indonesia oleh negara lain. Hal ini mungkin disebabkan kesulitan diagnosis penyakit ini di Indonesia. Pengetahuan mengenai epidemiologi, biologi jamur penyebab serta diagnosis penyakit ini diharapkan mampu meningkatkan kemampuan diagnosis penyakit ini di Indonesia.

\section{DAFTAR PUSTAKA}

1. Vanittanakom N, Cooper CR, Fisher MC, Sirisanthana T. Penicillium marneffei infection and recent advances in the molecular biology aspect. Clin Microbiol Rev. 2006;19(1):95-110.

2. Atalay A, Koc AN, Akyol G, Cak1r N, Kaynar L, Ulu-kilic A. Pulmonary infection caused by Talaromyces purpurogenus in a patient with multiple myeloma. Le Infez Med. 2016;2:153157.
3. Villanueva-Lozano G, Trevino-Rangel RJ, Renpenning-Carrasco EW, Gonzalez GM. Successful treatment of Talaromyces amestolkiae pulmonary infection with voriconazole in an acute lymphoblastic leukemia patient. J Infect Chemother. 2017;23:400-402.

4. Horre R, Gilges S, Breig P, et al. Case Report. Fungaemia due to Penicillium piceum, a member of the Penicillium marneffei complex. Mycoses. 2001;44:502-504.

5. Guevara-suarez M, Sutton DA, Gene J, et al. Four new species of Talaromyces from clinical sources. Mycoses. 2017;60:651-662.

6. Guevara-suarez M, Sutton DA, Cano-lira JF, et al. Identification and antifungal susceptibility of Penicillium-like fungi from clinical samples in the United States. J Clin Microbiol. 2016;54:21552161.

7. Santos PE, Piontelli E, Shea YR. Penicillium piceum infection: diagnosis and successful treatment in chronic granulomatous disease. Med Mycol. 2006;44:749-753.

8. Kok I, Veenstra J, Rietra P, Dirks-Go S, Blaauwgeers J, Weigel H. Disseminated Penicillium marneffei infection as an imported disease in HIV-1 infected patients. Description of two cases and a review of the literature. Neth J Med. 1994;44(1):18-22.

9. Wu TC, Chan JWM, Ng CK, Tsang DNC, Lee MP, Li PCK. Clinical presentations and outcomes of Penicillium marneffei infections: A series from 1994 to 2004. Hong Kong Med J. 2008;14:103-109.

10.Liyan X, Changming L, Xianyi Z, Luxia W, Suisheng $X$. Fifteen cases of penicilliosis in Guangdong, China. Mycopathologia. 2004; 158:151-155.

11.Duong TA. Infection due to Penicillium marneffei, an emerging pathogen: review of 155 reported cases. Clin Infect Dis. 1996;23:125-130.

12.DiSalvo AF, Fickling AM, Ajello L. Infection caused by Penicillium marneffei/ : Description of first natural infection in an. Am J Clin Pathol. 1973;59:259-263. 
13.Le T, Wolbers M, Chi NH, et al. Epidemiology, seasonality, and predictors of outcome of aidsassociated penicillium marneffei infection in Ho Chi Minh City, Viet Nam. Clin Infect Dis. 2011;52(7):945-952.

14.Chan JFW, Lau SKP, Yuen K, Woo PCY. Talaromyces (Penicillium) marneffei infection in non-HIV-infected patients. Emerg Microbes Infect. 2016;5(3):e19.

15.Hu Y, Zhang J, Li X. Penicillium marneffei Infection: An emerging disease in Mainland China. Mycopathologia. 2013;175:57-67.

16. Sirisanthana T, Supparatpinyo K. Epidemiology and management of penicilliosis in human immunodeficiency virus-infected patients. Int $\mathbf{J}$ Infect Dis. 1998;3:48-53.

17. Samson RA, Yilmaz N, Houbraken J. Phylogeny and nomenclature of the genus Talaromyces and taxa accommodatedin Penicillium subgenus Biverticillium. Stud Mycol. 2011;70:159-183.

18. Cooper CR, Vanittanakom N. Insights into the pathogenicity of Penicillium marneffei. Futur Microbiol. 2008;3(1):43-55.

19. Yilmaz N, Visagie CM, Houbraken J, Frisvad JC, Samson RA. Polyphasic taxonomy of the genus Talaromyces. Stud Mycol. 2014;78(1):175-341.

20.Boyce KJ, Andrianopoulos A. Morphogenetic circuitry regulating growth and development in the dimorphic pathogen Penicillium marneffei. Eukoryotic Cell. 2013;12(2):154-160.

21.Huang X, He G, Lu S, Liang Y, Xi L. Role of Rhizomys pruinosus as a natural animal host of Penicillium marneffei in Guangdong, China. Microb Biotechnol. 2015;8(4):659-664.

22. Cao C, Liang L, Wang W. Common reservoirs for Penicillium marneffei infection in humans and rodents, China. Emerg Infect Dis. 2011;17(2):209-214.

23. Chariyalertsak S, Vanittanakom P, Nelson KE, Sirisanthana T, Vanittanakom N. Rhizomys sumatrensis and Cannomys badius, new natural animal hosts of Penicillium marneffei. J Med Vet Mycol. 1996;34:105-110.

24. Stone A, Park BJ. Penicillium marneffei infection: Knowledge, gaps, and future directions.
Curr Fungal Infect Rep. 2011;5:193-198.

25. Viviani MA, Tortorano AM, Rizzardini G, et al. Treatment and serological studies of an Italian case of penicilliosis marneffei contracted in Thailand by a drug addict infected with the Human Immunodeficiency Virus. Eur J Epidemiol. 1993;9(1):79-85.

26. Kaufman L, Standard PG, Jalbert M, Kantipong P, Limpakarnjanarat K, Mastro TD. Diagnostic antigenemia tests for penicilliosis marneffei. J Clin Microbiol. 1996;34(10):2503-2505.

27. Cao L, Chen D, Lee C. Detection of specific antibodies to an antigenic mannoprotein for diagnosis of Penicillium marneffei penicilliosis. J Clin Microbiol. 1998;36(10):3028-3031.

28. Cao L, Chan K, Chen D. Detection of cell wall mannoprotein Mp1p in culture supernatants of Penicillium marneffei and in sera of penicilliosis Patients. 1999;37(4):981-986.

29. Huang Y, Hung C, Liao C, Sun H, Chang S, Chen $\mathrm{Y}$. Detection of circulating galactomannan in serum samples for diagnosis of Penicillium marneffei infection and cryptococcosis among patients infected with Human Immunodeficiency Virus. J Clin Microbiol. 2007;45(9):2858-2862.

30. Chaiwun B, Vanittanakom N, Jiviriyawat Y, Rojanasthien S, Thorner P. Investigation of dogs as a reservoir of Penicillium marneffei in northern Thailand. Int J Infect Dis. 2011;15:e236e239.

31. Vanittanakom N, Vanittanakom P, Hay RJ. Rapid identification of Penicillium marneffei by PCRbased detection of specific sequences on the rRNA gene. J Clin Microbiol. 2002;40(5):17391742.

32.Hien HTA, Thanh TT, Thu NTM, et al. Development and evaluation of a real-time polymerase chain reaction assay for the rapid detection of Talaromyces marneffei MP1 gene in human plasma. Mycoses. 2016;59:773-780.

33.Pongpom M, Sirisanthana T, Vanittanakom N. Application of nested PCR to detect Penicillium marneffei in serum samples. Med Mycol. 2009;47:549-553.

34.Lu S, Li X, Calderone R, et al. Whole blood Nested PCR and Real-time PCR amplification 
of Talaromyces marneffei specific DNA for diagnosis. Med Mycol. 2016;54:162-168.

35.Gugnani H, Fisher MC, Paliwal-Johsi A, Vanittanakom N, Singh I, Yadav PS. Role of Cannomys badius as a natural animal host of Penicillium marneffei in India. J Clin Microbiol. 2004;42(11):5070-5075.

36. Chariyalertsak S, Sirisanthana T, Supparatpinyo K, Praparattanapan J, Nelson KE. Case-control study of risk factors for Penicillium marneffei infection in Human Immunodeficiency Virusinfected patients in northern Thailand. Clin Infect Dis. 1997;24:1080-1086.
37. Chariyalertsak S, Sirisanthana T, Supparatpinyo K, Nelson KE. Seasonal variation of disseminated Penicillium marneffei infections in northern Thailand: A clue to the reservoir? J Infect Dis. 1996;173:1490-1493.

38. Pryce-miller E, Aanensen D, Vanittanakom N, Fisher MC. Environmental detection of Penicillium marneffei and growth in soil microcosms in competition with Talaromyces stipitatus. Fungal Ecol. 2008:49-56.

39. Hilmarsdottir I, Meybard JL, Rogeaux O, et al. Disseminated Penicillium marneffei infection associated with Human Immunodeficiency Virus: A report of two cases and a review of 35 published cases. J Acquir Immune Defic Syndr. 1993;6:466-471. 